\title{
IMPLEMENTASI KEBIJAKAN PENDIDIKAN LINGKUNGAN HIDUP SMP NEGERI 1 BAGAN SINEMBAH MENUJU SEKOLAH ADIWIYATA MANDIRI
}

\author{
Kiki Ardian \\ Makhdalena \\ Zulkifili N \\ 1)Post Graduate Student of Riau University \\ ${ }^{2)}$ Lecturer of Education Management Study Programme PPs University of Riau \\ ${ }^{3)}$ Lecturer of Education Management Study Programme PPs University of Riau
}

\begin{abstract}
Environmental education is one of important policy that isssued by the government as the effort of delivering education at whole schools by Adiwiyata programme. This research was aimed to obtain the description of the implementation environtmental education policy of SMP Negeri 1 Bagan Sinembah. The approach of the research used qualitative descriptive. Data collection was done by the researchers themselves as a key instrument, whereas to determine the source of human data using snowball sampling technique. Data was collected by means of; (1) in-depth interviews; (2) The participant observation; and (3) study the documentation. For data analysis using descriptive techniques whose application is done in three flow of activities, namely data reduction, data presentation, and conclusion or verification. The result showed that, first, the understanding of school people about the concept, goal and principle of Adiwiyata Mandiri was good. Second, the commitment of school people about the environment education policy was quite good eventhough some school people showed no spirit and unready attitude to run the Adiwiyata programme. Third, The programmes of Adiwiyata Mandiri were socializaiton to the candidate of next adiwiyata school, environmental education and Clean Saturday programme. The programmes runs quite well. Fourth, the implementor and financial source in implementing the environmental education policy at SMP Negeri 1 Bagan Sinembah was not adequate. The results can be taken into consideration for other schools in making their schools as Adiwiyata mandiri.
\end{abstract}

Key Words : Implementation, environtmental education, adiwiyata mandiri

ABSTRAK: Tujuan penelitian ini adalah untuk memperoleh gambaran secara nyata mengenai implementasi kebijakan Pendidikan Lingkungan Hidup SMP Negeri 1 Bagan Sinembah. Pendekatan yang digunakan dalam penelitian ini adalah pendekatan kualitatif. Pengumpulan data dilakukan oleh peneliti sendiri sebagai key instrument, sedangkan untuk menentukan sumber data manusia.Teknik pengumpulan data dilakukan dengan cara; (1) wawancara mendalam; (2) observasi berperanserta; dan (3) studi dokumentasi. Untuk analisis data menggunakan teknik deskriptif yang penerapannya dilakukan dalam tiga alur kegiatan, yaitu reduksi data, penyajian data, dan penarikan kesimpulan atau verifikasi. Hasil penelitian menunjukkan bahwa, pertama, pemahaman warga sekolah tentang konsep adiwiyata mandiri, tujuan dan prinsip adiwiyata sudah baik. Kedua, komitmen warga sekolah terhadap kebijakan pendidikan lingkungan hidup sangat baik walaupun sebagian warga menunjukkan sikap kurang semangat dan siap menjalankan program program adiwiyata. Ketiga, program program yang dilaksanakan dalam mewujudkan sekolah Adiwiyata Mandiri adalah pembinaan ke sekolah calon adiwiyata, pembelajaran lingkungan hidup dan kegiatan Sabtu bersih. Pelaksanaan program juga berjalan dengan baik. Keempat, ketersediaan sumberdaya dibagi menjadi dua aspek yaitu ketersediaan 
sumberdaya pelaksana dan ketersediaan sumberdaya finansial. Sumberdaya pelaksana dan sumberdaya finansial dalam implementasi kebijakan pendidikan lingkungan hidup di SMP Negeri 1 Bagan Sinembah dalam upaya mewujudkan sekolah Adiwiyata Mandiri masih belum memadai. Hasil penelitian ini dapat dijadikan pertimbangan dalam menjadikan sekolah sebagai sekolah adiwiyata mandiri.

Kata kunci: Implementasi, pendidikan lingkungan hidup , adiwiyata mandiri

\section{PENDAHULUAN}

Pendidikan dalam rangka mencerdaskan kehidupan bangsa seyogyanya ditandai dengan konsistensi penyelenggara pendidikan dalam memberdayakan peserta didik. Pendidikan yang memberdayakan adalah proses memanusiakan anak sehingga potensinya menjadi aktual dalam kematangan dan kemandirian hidupnya. Paling tidak pendidikan yang memberdayakan, setiap anak akan mendapatkan basic need, dapat mengetahui hak dan tanggung jawabnya sebagai individu, anggota masyarakat dan sebagai makhluk Tuhan. Pendidikan yang memberdayakan seharusnya terus diusahakan mulai dari pendidikan usia dini, sekolah dasar, menengah, sampai dengan perguruan tinggi (Syafaruddin, 2008)

Pendidikan lingkungan hidup merupakan salah satu kebijakan penting yang telah dibuat pemerintah. Diamanatkan dalam Undang-undang (UU) Nomor 32 Tahun 2009 pasal 65 ayat 2 bahwa setiap orang berhak mendapatkan pendidikan lingkungan hidup. Dinyatakan juga dalam Undang-undang tersebut bahwa pemerintah dapat memberikan pendidikan, pelatihan, pembinaan dan penghargaan kepada orang atau lembaga yang berjasa dibidang lingkungan hidup.

Pemerintah Republik Indonesia dalam hal ini kementerian lingkungan hidup juga telah melakukan upaya dalam memberikan pendidikan di sekolah sekolah dalam mengelola lingkungan hidup didalam program Adiwiyata. Melalui program Adiwiyata diharapkan dapat meningkatkan kepedulian masyarakat khususnya stakeholder pendidikan terhadap masalah lingkungan yang dihadapi, meningkatkan peran serta aktif masyarakat dalam menanggulangi masalah lingkungan hidup, mewujudkan sumber daya manusia (SDM) yang memiliki karakter bangsa terhadap perkembangan ekonomi, sosial, dan lingkungannya dalam mencapai pembangunan berkelanjutan di daerah.

Sekolah Menengah Pertama Negeri 1 Bagan Sinembah berlokasi di Kecamatan Bagan Sinembah. SMP ini terletak di ujung bagian utara Propinsi Riau atau di perbatasan dengan Sumatera Utara. Sekolah ini merupakan salah satu SMP terbesar di Kecamatan Bagan Sinembah. Diantara prestasi yang menonjol adalah menjadi sekolah adiwiyata nasional tahun 2014, juara 1 lomba sekolah sehat tingkat propinsi dan menjadi finalis tingkat nasional dan terakhir menjadi juara pertama lomba tata kelola dana bos tingkat propinsi Riau dan menjadi terbaik ke 14 tingkat nasional.

Penelitian ini difokuskan pada pengkajian Implementasi Kebijakan Pendidikan Lingkungan Hidup di SMP Negeri 1 Bagan Sinembah Menuju Sekolah Adiwiyata Mandiri. Adapun subfokus penelitian ini adalah pemahaman warga sekolah tentang Adiwiyata Mandiri di SMP Negeri 1 Bagan Sinembah, komitmen warga sekolah dalam mewujudkan sekolah Adiwiyata Mandiri, program pendidikan lingkungan hidup dan ketersediaan sumberdaya dalam implementasi kebijakan pendidikan lingkungan hidup di SMP Negeri 1 Bagan Sinembah menuju sekolah Adiwiyata Mandiri.

Hasil Penelitian tentang Implementasi kebijakan Pendidikan Lingkungan Hidup Sekolah Menengah Pertama Negeri 1 Bagan Sinembah Menuju Sekolah Adiwiyata Mandiri ini diharapkan bermanfaat bagi berbagai pihak terkait antara lain untuk memberikan pemahaman tentang kebijakan Pendidikan Lingkungan Hidup 
dan implementasinya dalam mewujudkan sekolah adiwiyata mandiri, dan sebagai bahan diskusi dan informasi yang valid untuk implementor sekolah sekolah adiwiyata untuk menjadi sekolah adiwiyata mandiri.

Selain itu, secara praktis penelitian ini berguna sebagai gambar atau potret dalam mengimplementasikan kebijakan Pendidikan Lingkungan Hidup untuk menuju Sekolah Adiwiyata Mandiri dan bagi mitra sekolah yaitu calon sekolah adiwiyata, calon adiwiyata mandiri, Bapedal Kabupaten Rokan Hilir, Balai Lingkungan Hidup Propinsi Riau sebagai upaya peningkatan pembinaan sekolah yang berwawasan dan berbudaya lingkungan. Dan untuk para pengambil kebijakan, diharapkan dapat memahami permasalahan-permasalahan dan hambatan-hambatan yang dialami berkenaan dengan implementasi kebijakan Pendidikan Lingkungan Hidup untuk menuju sekolah Adiwiyata Mandiri.

Program Adiwiyata merupakan amanah Undang-undang nomor 32 tahun 2009 tentang Perlindungan dan Pengelolaan Lingkungan Hidup dan Peraturan Menteri Negara Lingkungan Hidup nomor 02 tahun 2009 tentang pedoman pelaksanaan program Adiwiyta dan disempurnakan menjadi kebijakan Pendidikan Lingkungan Hidup antara Menteri Negara Lingkungan Hidup dengan Menteri Pendidikan Nasional No.03/MenLH/02/2010, No.01/II/ KB/2010 tanggal 1 Februari 2010 tentang Pendidikan Lingkungan Hidup melalui program Adiwiyata. Dan yang pedoman pelaksanaan program adiwiyata yang teranyar diterbitkan oleh Menteri Lingkungan Hidup Republik Indonesia yang sekarang berubah menjadi Kementerian Kehutanan dan Lingkungan Hidup Nomor 05 tahun 2013.

Menurut Daryanto dan Suprihatin bahwa Pendidikan Lingkungan Hidup bertujuan mendorong dan memberikan kesempatan kepada masyarakat memperoleh pengetahuan, keterampilan dan sikap yang pada akhirnya dapat menumbuhkan kepudilan, komitmen untuk melindungi, memperbaiki serta memanfaatkan lingkungan hidup secara bijaksana, turut menciptakan perilaku baru yang bersahabat dengan lingkungan hidup, mengembangkan etika lingkungan hidup dan memperbaiki kualitas hidup.

Kebijakan Pendidikan Lingkungan Hidup melalui Program Adiwiyata dilakukan melalui pembinaan seperti tertera dalam Lampiran II Peraturan Menteri Lingkungan Hidup Republik Indonesia Nomor 05 Tahun 2013 yang bertujuan untuk: a) meningkatkan kapasitas sekolah untuk mewujudkan Sekolah Adiwiyata atau sekolah peduli dan berbudaya lingkungan, b) meningkatkan kapasitas kelembagaan dan sumber daya manusia dalam pengelolaan Program Adiwiyata dan, c) meningkatkan pencapaian kinerja pengelolaan adiwiyata baik di propinsi maupun di kabupaten/kota termasuk sekolah dan masyarakat sekitarnya.

Berdasarkan Peraturan Menteri Lingkungan Hidup Nomor 05 Tahun 2013 pada lampiran IV tentang Pedoman Pelaksanaan Program Adiwiyata seperti diuraikan pada latar belakang penelitian ini bahwa Adiwiyata Mandiri adalah: (1) tim penilai adiwiyata nasional menetapkan sekolah adiwiyata nasional yang akan dilakukan verifikasi berdasarkan usulan dari provinsi, (2) sekolah adiwiyata nasional yang terpilih, dilakukan verifikasi, (3) penetapan sekolah sebagai penerima penghargaan sekolah adiwiyata mandiri apabila sekolah adiwiyata nasional tersebut telah melakukan pembinaan terhadap sekolah lain, paling sedikit 10 (sepuluh) sekolah, dan sekolah yang dibina tersebut telah mendapatkan penghargaan adiwiyata kabupaten/ kota, (4) sekolah adiwiyata mandiri dapat diusulkan untuk ikut dalam seleksi penerimaan penghargaan tingkat Asean Eco School.

\section{METODE PENELITIAN}

Pendekatan yang digunakan dalam penelitian ini adalah pendekatan kualitatif. Pengumpulan data dilakukan oleh peneliti sendiri sebagai key instrument. Teknik pengumpulan data dilakukan dengan cara; (1) wawancara (2) observasi dan (3) studi dokumentasi. Untuk 
analisis data menggunakan teknik deskriptif yang penerapannya dilakukan dalam tiga alur kegiatan, yaitu reduksi data, penyajian data, dan penarikan kesimpulan atau verifikasi. Untuk mengetahui kredibilitas data, dilakukan dengan berbagai teknik, yaitu (1) triangulasi; (2) keterlibatan yang lama antara peneliti dengan yang diteliti yaitu sekolah dan mitra sekolah.

\section{HASIL DAN PEMBAHASAN}

Penelitian ini bertujuan untuk menggambarkan tentangimplementasi kebijakan pendidikan lingkungan hidup di SMP Negeri 1 Bagan Sinembah menuju sekolah Adiwiyata Mandiri. Untuk dapat mendeskripsikan dan menganalisis tujuan penelitian ini difokuskan ke dalam empat subfokus yaitu: (1) pemahaman warga sekolah tentang Adiwiyata Mandiri di SMP Negeri 1 Bagan Sinembah, (2) komitmen warga sekolah dalam mewujudkan sekolah Adiwiyata Mandiri, (3) program pendidikan lingkungan hidup dan (4) ketersediaan sumberdaya dalam implementasi kebijakan pendidikan lingkungan hidup di SMP Negeri 1 Bagan Sinembah menuju sekolah Adiwiyata Mandiri.

Berdasarkan hasil wawancara dapat diketahui bahwa pada subfokus pemahaman warga sekolah tentang konsep adiwiyata mandiri sudah cukup baik sesuai dengan kata kunci walaupun belum sempurna dan masih perlu diluruskan pemahaman mengenai prinsip program adiwiyata dan pemahaman tentang perbedaan antara sekolah adiwiyata nasional dan adiwiyata mandiri.

Kemudian untuk subfokus komitmen warga sekolah dalam mewujudkan sekolah adiwiyata mandiri warga sekolah menyatakan menerima program dengan baik dan meyakini bahwa program memberikan kontribusi yang positif dalamupaya pengelolaan dan perlindungan lingkungan hidup dan telah dibuktikan dengan berbagai hasil yang telah diperoleh sekolah. Dan pada sisi kesiapan melaksanakan program, pada umumnya warga sekolah bersedia menjalankan setiap program adiwiyata walaupun ditemukan sebagian warga menunjukkan sikap kurang semangat dan peduli terhadap program.

Sementara pada subfokus program pendidikan lingkungan hidup, ditemukan bahwa program sedang dijalankan adalah kegiatan pembinaan ke calon sekolah adiwiyata, pembelajaran PLH dan kegiatan Sabtu bersih.

Pada sisi pelaksanaan program, disimpulkan bahwa pelaksanaannya berjalan dengan baik.

Dan yang terakhir adalah subfokus ketersediaan sumberdaya. Hasil dari metode penelitian yaitu berupa observasi, dokumentasi dan wawancara kepada informan diperoleh informasi bahwa ketersediaan sumberdaya pelaksana dan sumberdaya finansial masih belum memadai untuk dapat mengimplementasikan kebijakan pendidikan lingkungan hidup di SMP Negeri 1 Bagan Sinembah menuju sekolah Adiwiyata Mandiri.

\section{SIMPULAN DAN SARAN}

Berdasarkan data yang diperoleh dari wawancara, observasi dan dokumentasi tentang implementasi kebijakan pendidikan lingkungan hidup di SMP Negeri 1 Bagan Sinembah menuju adiwiyata mandiri, dapat disimpulkan bahwa:

1. Pemahaman warga sekolah tentang konsep adiwiyata mandiri, tujuan dan prinsip adiwiyata sudah baik.

2. Komitmen warga sekolah terhadap kebijakan pendidikan lingkungan hidup sangat baik walaupun sebagian warga menunjukkan sikap kurang semangat dan siap menjalankan program program adiwiyata;

3. Program program yang dilaksanakan dalam mewujudkan sekolah Adiwiyata Mandiri adalah pembinaan ke sekolah calon adiwiyata, pembelajaran lingkungan hidup dan kegiatan Sabtu bersih. Pelaksanaan program juga berjalan dengan baik.

4. Ketersediaansumberdaya dibagi menjadi dua aspek yaitu ketersediaan sumberdaya pelaksana dan ketersediaan sumberdaya finansial. Sumberdaya pelaksana dan sumberdaya finansial dalam implementasi 
kebijakan pendidikan lingkungan hidup di SMP Negeri 1 Bagan Sinembah dalam upaya mewujudkan sekolah Adiwiyata Mandiri masih belum memadai.

Berdasarkan temuan dan hasil pembahasan penelitian serta kesimpulan, maka kami memberi rekomendasi sebagai berikut :

Dari hasil temuan penelitian dan parapan simpulan diatas, maka direkomendasikan:

1. Prinsip program adiwiyata adalah edukatif, partispatif dan berkelanjutan. Oleh sebab itu implementasi program adiwiyata di SMP Negeri 1 Bagan Sinembah meski sudah menunjukkan keberhasilannya di tingkat nasional, namun hendaknya warga sekolah harus meningkatkan pemahaman dan prestasi untuk mewujudkan sekolah adiwiyata mandiri.

2. Perlunya ditingkatkan komitmen terhadap program adiwiyata sehingga setiap warga sekolah merasa berkepentingan untuk melaksanakan program pendidikan lingkungan hidup sebagai upaya perlindungan dan pengelolaan lingkungan hidup.

3. Program program adiwiyata yang ada perlu mendapat dukungan dari setiap warga sekolah dan stakeholder yang ada sehingga kualitas program dapat ditingkatkan baik dari jenis kegiatan maupun pelaksanaannya.

4. Ketersediaan sumberdaya pelaksana dan finansialmasihbelum memadai sehinggaperlu didukung dengan melaksanakan pembinaan terhadap pelaksana adiwiyata di sekolah dan pemberian bantuan biaya dalam implementasi kebijakan pendidikan lingkungan hidup dalam mewujudkan sekolah Adiwiyata Mandiri.

\section{DAFTAR PUSTAKA}

Daryanto dan Agung Suprihatin, 2013. Pengantar Pendidikan Lingkungan Hidup. Yogyakarta:Gava Media

Jhon W. Creswell, alih bahasa Muhammad Diah Z, 2011. Penelitian Kualitatif dalam Bidang Pendidikan, Pekanbaru: UMRI Press.
Sugiyono. 2013. Metode penelitian manajemen, Yogyakarta: Alfabeta

Wayne Parsons. 2005. Public Policy: Pengantar Teori \& Praktik Analisis Kebijakan. Jakarta: Prenada Media

Erwan Agus Purwanto, \& Dyah Ratih Sulistyastuti 2011. Implementasi Kebijakan Publik, Jakarta: Penerbit Gava Media.

Syafaruddin, 2008, Efektivitas Kebijakan Pendidikan, Penerbit Rineka Cipta, Jakarta

Mazmanian, Daniel A and Paul A. Sabatier,1983. Implementation and Public Policy, Scott Foresman and Company, USA,

Wibowo Eddi,2004, KebijakanPublik Dan Budaya, YPAPI, Yogyakarta.

Subarsono AG, 2006, Analisis Kebijkaan Publik, Pustaka Pelajar, Yogyakarta

SagalaSyaiful,2010,Manajemen Strategik dalamPeningkatan

MutuPendidikan,PenerbitAlfabeta,Bandung.

W.J.S. Porwadarminta, KamusBesarBahasa Indonesia, Jakarta: BalaiPustaka, 1991.

AnasSudijono, Pengantar Evaluasi Pendidikan, Jakarta: Raja Grafindo Persada, 1996.

Robbins SP, dan Judge. Perilaku Organisasi, Jakarta : Salemba Empat, 2007

Sopiah. 2008. Perilaku Organisasi, Yogyakarta :Andi

Theresia Melania Sudarwati,. 2012. Implementasi Kebijakan Pendidikan Lingkungan Hidup Sekolah Menengah Atas Negeri 11 Semarang Menuju Sekolah Adiwiyata. Jurnal. Universitas Dipenogoro Semarang

Pariang Sonang Siregar,. 2015. Implementasi Kebijakan Program Adiwiyata Sekolah Dalam Pencapaian Visi SMA Negeri 2 Rambah Hilir. Jurnal. Universitas Riau

Kementerian Lingkungan Hidup, 2013. Panduan Adiwiyata Sekolah Peduli dan Berbudaya Lingkungan. Kerjasama Kementerian Lingkungan Hidup dengan Kementerian Pendidikan dan Kebudayaan 
Kebijakan dan Undang-undang yang berkaitan dengan Penelitian:

Peraturan Menteri Lingkungan Hidup Nomor 5

Tahun 2013 tentang Pedoman Pelaksanaan

Program Adiwiyata
DepatemenPendidikan Nasional.2003. UndangUndangRepublik Indonesia Nomor 20 Tahun 2003 tentang Sistem Pendidikan Nasional. Jakarta.

Undang-undang Nomor 32 Tahun 2009 tentang Perlindungan dan Pengelolaan Lingkungan 